\title{
Primary School Students' Learning Toward The Use of VBA For Excel Based Games In Learning Number
}

\author{
Martin Bernard ${ }^{1}$, Arif Sunaryo ${ }^{2}$, Padillah Akbar $^{3}$ \\ ${ }^{1,2}$ Department of Mathematics Education, Faculty of Mathematics and Science Education, Institute Keguruan dan Ilmu \\ Pendidikan Siliwangi, Jl. Terusan Jenderal Sudirman, Cimahi, Indonesia \\ ${ }^{3}$ SMP Putra Juang, Jl. Cipetir Sukatani, Haurwangi, Cianjur, Indonesia \\ pamartin23rnard@gmail.com
}

\begin{abstract}
The purpose of this study was to describe the learning motivation of students of SD Negeri in Cianjur where elementary school students experienced difficulty in processing integer arithmetic operations, due to the lack of mastery of students' understanding of the basics of integer concept and integer operation so that students were able to develop mathematical applications. The research method used is descriptive qualitative method. The research subjects were 25 students of SD Negeri in Cianjur grade VI. The instrument given was a questionnaire on the scale of student learning motivation consisting of 20 statements and 4 answer choices. The learning motivation questionnaire related to the VBA for Excel-based ICT media consists of 4 indicators. The results showed that the learning motivation of SD Negeri Cianjur students using ICT media assisted by VBA for Excel on number line material as a whole is classified as very good and there are 3 indicators that are very good criteria, namely for indicators of confidence in using mathematics (very good), Flexible indicators in doing math work (very well); Indicators of Willingness to leave other obligations or duties, (very good). There is 1 indicator that falls into the good criteria, namely the persistence indicator in doing mathematics (good).
\end{abstract}

Keywords: Student Learning Motivation, VBA for Excel, The number line.

\begin{abstract}
Abstrak
Tujuan penelitian ini adalah untuk mendeskripsikan motivasi belajar siswa SD Negeri di Cianjur dimana siswa Sekolah Dasar mengalami kesulitan proses dalam operasi hitung bilangan bulat, disebabkan kurangnya penguasaan kemampuan pemahaman siswa tentang dasar-dasar konsep bilangan bulat dan operasi bilangan bulat sehingga siswa mampu mengembangkan aplikasi matematika. Metode penelitian yang digunakan adalah metode kualitatif deskriptif. Subjek penelitian yang dilakukan yaitu pada 25 siswa SD Negeri di Cianjur kelas VI. Instrumen yang diberikan berupa angket skala motivasi belajar siswa yang terdiri dari 20 pernyataan dan 4 pilihan jawaban. Angket motivasi belajar yang berhubungan dengan media ICT berbasis VBA for Excel terdiri dari 4 indikator. Hasil penelitian menunjukan bahwa motivasi belajar siswa SD Negeri di Cianjur dengan menggunakan media ICT berbantuan VBA for Excel pada materi garis bilangan secara keseluruhan tergolong sangat baik dan terdapat 3 indikator yang masuk kriteria baik sekali yaitu untuk indikator Percaya diri dalam menggunakan matematika (sangat baik), indikator Flekibel dalam melakukan kerja matematika (sangat baik); indikator Kerelaan meninggalkan kewajiban atau tugas lain, (sangat baik). Terdapat 1 indikator yang masuk kriteria baik yaitu indikator Ketekunan dalam mengerjakan matematika (baik).
\end{abstract}

Kata Kunci: Motivasi Belajar, VBA for Excel, Garis Bilangan

Copyright (c) 2021 Martin Bernard, Arif Sunaryo, Padillah Akbar

$\triangle$ Corresponding author: Padillah Akbar

Email Address: dilakbar07@gmail.com (Jl. Terusan Jendral Sudirman, Cimahi, Jawa Barat, Indonesia)

Received 16 November 2020, Accepted 03 Maret 2021, Published 13 Maret 2021

\section{PENDAHULUAN}

Mathematics is one of subjects that is taught from primary students up to university, due to the importance of maths in all aspects (Bernard, M., Akbar, P., Ansori, A., \& Filiestianto, 2019). For example selling and buying, seeing time, transactional instrument, etc. Besides that, maths is one of the science which supports and plays a role in Technology and Science Development. By that, maths is very important to be learnt by students and maths were present at all education levels. Learning 
maths is one maths learning process which can train student how to think critically and logically and creatively (Nugraha, Kadarisma, \& Setiawan, 2018, Wiliawanto, et. al., 2019, Bernard \& Sunaryo, 2020).

However, a lot of students think that mathematics is difficult. To remove or change the student perception that maths is difficult, a teacher must be able to create a condition or a process which is able to lead the students to do learning activity. A teacher plays an important role in motivating students as it is one of his/her assignment. Teaching is one of the factor of the success or student development (M. Bernard et al., 2019, Akbar, et. al, 2018). Students who just join the class without any motivation would not achieve a good outcome from the learning process. Therefore, a teacher's attention towards a right concept of understanding and student motivation would be high in learning process (Sunaryo, 2019). Based on the research by Pebriana (2017), students' maths learning motivation is still low resulting low learning result. It can be seen by not many students achieve Minimal Passing Criteria, which is set by school that is 70. From all students, only $45 \%$ passed.

Using media in learning process is one of the way that can be used to increas student learning motivation. According to Bernard (2018), learning media in maths is one way to give a description to student that they can understand how to apply various problems related to maths. Attractive media will affect student learning motivation, one of learning media that was chosen was ICT For VBA Based on Microsoft Excel.

Microsoft Excel is a software which provides images in various measures and shapes so that researcher could design the reseacrh according to the need and materials presentation needs. In Microsoft, Excel pictures can be moved to make an interesting game, especially for primary students on the number line subject which can be a mischief to students and slow down student understanding. The order to make an object or pictures in Microsoft Excel to become interactive is by writing down Basic Visual Application to code Microsoft Excel as soon as VBA can run the program and the result was the object or picture changed from stationary to dynamic (Bernard, Novtiar \& Rohaeti, 2020).

Based on the above mentioned background, an introduction study titled "Analysis of Learning Motivation of Padawaras Cianjur Primary Student using ICT Media based on VBA for Excel on the Number Line was conducted". The researcher sees the importance of the number line. The subject of the number line was served as how to operate positive and negative integers, in which students made a lot of mistakes.

\section{METHOD}

The type of research was descriptive qualitative. It is aimed at analysing learning motivation of PadawarasCianjur primary using ICT based on VBA for Excel on The Number line which is guided by the fullfilment of learning motivation indicators. Previously the media has been examined for its appropriateness by media expert (a lecturer of TIK application: Inovative mathematics and material expert: a lecturer of primary student maths solving problems). The subject of this research was 25 
primary students Class VI in SD Padawaras Cianjur. The research was commenced at the beginning of even semester in $2019-2020$. The data collection in the research was by a scaled questionnaire of learning motivation. This instrument was used as an effort to get primary data in learning motivation in primary student class VI. The researcher explained the number line subject using ICT media based on VBA for Excel and then the students gave their responses in the questionnaires.

The instrument used in the reserach was a scaled learning motivation questionnaire related to ICT media based on VBA for Excel. Then the indicators were given scores and the overall scores are converted in scale form (1-100) and the data was interpreted according to the understanding criteria based on Arikunto (2008). Data were catagorised as a range found by Arikunto (2008), and the range can be observed as follow (Table1):

Table 1. Data Criteria

\begin{tabular}{|c|c|}
\hline Percentage & Criteria \\
\hline $81-100$ & Excellent \\
\hline $61-80$ & Good \\
\hline $41-60$ & Enough \\
\hline $21-40$ & Lack \\
\hline $1-20$ & Very Lacking \\
\hline
\end{tabular}

\section{RESULT AND DISCUSSION}

Based on the test conducted, it could be seen that the ability of the students in the PadawarasCianjur Primary School using ICT Media based on VBA for Excel on the Number Line subject. This instrument was in the form of learning motivation questionnaire consisted of 6 indicators of 20 scaled statements. The questionnaire has 4 answer options, that was completely agree (CA), Agree (A), Disagree (D) and Completely Disagree (CD). The questionnaire was given as a closed questionaire to 25 students. The questionnaire data analysis was tabulated and the answers are converted into percentages.

Table 2. Percentage of Learning Interest Questionnaire

\begin{tabular}{|c|l|c|c|c|c|}
\hline No & \multicolumn{1}{|c|}{ Statement } & \multicolumn{4}{c|}{ Response (\%) } \\
\hline A & Indicator: Self confidence in using maths & CA & A & D & CD \\
\hline 1 & $\begin{array}{l}\text { I love learning maths which was explained } \\
\text { by teacher using ICT media ICT based on } \\
\text { VBA for Excel (+) }\end{array}$ & 91.43 & 8.57 & 0.00 & 0.00 \\
\hline 2 & $\begin{array}{l}\text { I don't understand maths subject clearly } \\
\text { which was explained by teacher using ICT } \\
\text { media based on VBA for Excel (-) }\end{array}$ & 2.86 & 5.60 & 54.29 & 37.25 \\
\hline B & $\begin{array}{l}\text { Indicator: Flexibility in doing maths } \\
\text { activity }\end{array}$ & CA & $\mathbf{A}$ & D & CD \\
\hline 3 & $\begin{array}{l}\text { I felt that I lost something if I miss a subject } \\
\text { in maths (+) }\end{array}$ & 37.14 & 37.14 & 8.57 & 17.14 \\
\hline 4 & $\begin{array}{l}\text { I feel that the time alloted to learn maths in } \\
\text { class was too much (-) }\end{array}$ & 2.86 & 5.71 & 57.14 & 34.29 \\
\hline 5 & $\begin{array}{l}\text { I'm not satisfied if the teacher explains } \\
\text { maths using ICT media based on VBAfor } \\
\text { Excel was in a rush (+) }\end{array}$ & 22.86 & 14.29 & 45.71 & 17.3 \\
\hline
\end{tabular}


Primary School Students' Learning Toward The Use of VBA For Excel Based Games In Learning Number, Martin Bernard, Arif Sunaryo, Padillah Akbar

\begin{tabular}{|c|l|c|c|c|c|}
\hline 6 & I come late for maths (-) & 0.00 & 2.86 & 71.43 & 25.71 \\
\hline $\mathbf{C}$ & $\begin{array}{l}\text { Indicator: Willingness to leave other } \\
\text { obligation or other tasks }\end{array}$ & $\mathbf{C A}$ & $\mathbf{A}$ & $\mathbf{D}$ & $\mathbf{C D}$ \\
\hline 7 & I learn maths as school makes me to (+) & 48.57 & 48.57 & 0.00 & 2.86 \\
\hline 8 & $\begin{array}{l}\text { I avoided learning maths as there was too } \\
\text { many homeworks (-) }\end{array}$ & 0.00 & 0.00 & 71.43 & 28.57 \\
\hline 9 & $\begin{array}{l}\text { I prioritise maths lessons over other subjects } \\
\text { (+) }\end{array}$ & 20.00 & 17.14 & 51.43 & 11.43 \\
\hline 10 & $\begin{array}{l}\text { I was bored in learning maths using ICT } \\
\text { media based on VBA for Excel (-) }\end{array}$ & 0.00 & 5.71 & 60.11 & 34.29 \\
\hline $\mathbf{D}$ & $\begin{array}{l}\text { Indicator: Perseverence in doing maths } \\
\text { obligation or other tasks }\end{array}$ & $\mathbf{C A}$ & $\mathbf{A}$ & $\mathbf{D}$ & $\mathbf{C D}$ \\
\hline 11 & $\begin{array}{l}\text { I made notes when the teacher explains } \\
\text { using ICT media based on VBA for Excel } \\
\text { (+) }\end{array}$ & 14.29 & 85.71 & 0.00 & 0.00 \\
\hline 12 & $\begin{array}{l}\text { I didn't pay attention when my friends } \\
\text { asked about maths (-) }\end{array}$ & 0.00 & 28.57 & 51.43 & 20.00 \\
\hline 13 & $\begin{array}{l}\text { I love to participate in maths discussion in } \\
\text { class (+) }\end{array}$ & 57.14 & 42.86 & 0.00 & 0.00 \\
\hline 14 & I felt anxious when learning maths (-) & 0.00 & 0.00 & 71.43 & 28.57 \\
\hline $\mathbf{E}$ & $\begin{array}{l}\text { Indicator: Students are able to make a } \\
\text { stance for their opinions }\end{array}$ & $\mathbf{C A}$ & $\mathbf{A}$ & $\mathbf{D}$ & $\mathbf{C D}$ \\
\hline 15 & $\begin{array}{l}\text { I tried hard to find a solution for difficult } \\
\text { maths problems (+) }\end{array}$ & 48.57 & 42.86 & 8.57 & 0.00 \\
\hline 16 & $\begin{array}{l}\text { I refused my friends opinion during } \\
\text { discussions (-) }\end{array}$ & 2.86 & 0.00 & 65.71 & 31.43 \\
\hline 17 & $\begin{array}{l}\text { Learning maths individually made me } \\
\text { understand maths better (+) }\end{array}$ & 71.43 & 25.71 & 2.86 & 0.00 \\
\hline $\mathbf{F}$ & $\begin{array}{l}\text { Indicator: Perseverence in doing maths } \\
\text { tasks }\end{array}$ & $\mathbf{C A}$ & $\mathbf{A}$ & $\mathbf{D}$ & $\mathbf{C D}$ \\
\hline 18 & $\begin{array}{l}\text { I endure in sloving maths questions until I } \\
\text { finish all of them (+) }\end{array}$ & 42.86 & 42.86 & 14.29 & 0.00 \\
\hline 19 & $\begin{array}{l}\text { I refused to participate when there were } \\
\text { long discussions of maths (-) }\end{array}$ & 0.00 & 11.43 & 60.00 & 28.57 \\
\hline 20 & \begin{tabular}{l} 
I stopped asking questions \\
\hline
\end{tabular} & 8.57 & 5.71 & 37.14 & 48.57 \\
\hline
\end{tabular}

Based on the result above, the learning outcome of using ICT media based on VBA for Excel towards primary student learning motivation will be discussed. There were 5 statements and 4 indicators which were related to the ICT media based on VBA for Excel could be found in statements number $1,2,5,10$, and 11 . On the first indicator which was self confidence in using maths, in statement number 1 and 2, while statement number 1 was positive, all of the students responded completely agree, which gave a total $100 \%$ percentage. The statement was "I love learning maths which was explained by teacher using ICT media ICT based on VBA for Excel" so it can be concluded that students love learning maths using ICT media based on VBA for Excel (Excellent).

In the negative second statement, almost of the students gave completely disagree responses by a total percentage of $91.54 \%$. The statement was "I don't understand maths subject clearly which was explained by teacher using ICT media based on VBA for Excel" so it can be students understood maths explained by the teacher using ICT media based on VBA for Excel clearly (Excellent). 
In the second indicator that is flexibility in doing maths, in the fifth statement which has positive value, a lot of students responded disagree and completely disagree which cab be converted into a total percentage of $62.74 \%$. The statement was "I'm not satisfied if the teacher explains maths using ICT media based on VBA for Excel was in a rush" so it could be concluded that students were not satisfied if the teacher explained maths using ICT media based on VBA for Excel in a hurry (Good).

In the third indicator that is the willingness to leave other obligation or other tasks which can be found in the tenth statement which has negative value, most students responded disagree and completely disagree giving a total percentage of $94.40 \%$. The statement was "I was bored in learning maths using ICT media based on VBA for Excel" so it could be concluded that students were not bored learning maths using ICT media based on VBA for Excel (Excellent).

In the fourth indicator that was perseverence in doing maths, chich can be found in the 11th statement which has positive value, all of the students gave agree responses which gave a total percentage of $100 \%$. The statement was "I made notes when the teacher explains using ICT media based on VBA for Excel" so it could be concluded that students made notes when the teacher explained the subjects using ICT media based on VBA for Excel (Excellent).

Based on the explanation of 5 statemnts and 4 indicators above, it could be concluded that using ICT media ICT based on VBA for Excel in learning maths can increase student learning motivation. This is in accordance with the research conducted by Bernard (2018) that the implementation of math learning using ICT media based on VBA for Excel can help students solve maths problems easily and increase studentsmaths learning motivation. It was also mentioned in Mahmud's research result (2015) that class 5 SDN Model TerpaduMadani students' motivation and learning outcomes who joined the learning using media based on ICT were better than the usual learning. From Rizki's result (2015) learning based on ICT gave satisfactory results in learning process. Furthermore, from the data analysis result, it can be concluded that there was a significant effect in students learning motivation when ICT was applied. Martin Bernard \& Senjayawati, (2019) also mentioned that VBA for Excel learning was more interesting and inreasing the students' motivation in learning maths and improves students' learning outcomes. Media design was obtained from students' difficulty in understanding the operation of positive and negative integers according to the observation and direct interview with the class VI about students' difficulty in knowing the meaning of integer, substraction and addition operation concept and making reasons in forms of results anwers.

Table 3. Observation Result Based on Student Ability before Using Media

\begin{tabular}{|c|l|c|c|c|c|}
\hline No & \multicolumn{1}{|c|}{ Student ability statement } & Able & Percentage & Unable & Percentage \\
\hline 1 & $\begin{array}{l}\text { Understand the meaning of positive } \\
\text { integer, zero and negative integer }\end{array}$ & 10 & $40 \%$ & 15 & $60 \%$ \\
\hline 2 & $\begin{array}{l}\text { Understand how to solve the addition } \\
\text { and substraction operation between 2 } \\
\text { integers. }\end{array}$ & 8 & $32 \%$ & 17 & $68 \%$ \\
\hline 3 & Able to give a final conclusion & 14 & $58 \%$ & 11 & $44 \%$ \\
\hline
\end{tabular}


Based on table 3, that a) 10 students who are able to understand integers 8 people mention differences in positive and negative symbols but have not been able to interpret for reasons that are easily understood, 2 students can provide an explanation of the difference using profit and loss stories but can understand concretely. For statement b) among 8 students experienced, 3 students said they could give an answer but still got the wrong result, 3 students had worked but were still doubtful of the answer, and 2 students said they could work on the addition problem but needed a hint. For statement c) 14 students are able to provide results conclusions, 12 students are able to explain the final result but are unable to provide an explanation of the reasons and 2 students provide an explanation but by providing an explanation using symbols in the abstract or limited by numbers.

The media is designed based on the results of student observations and interviews to overcome the difficulties students have encountered.

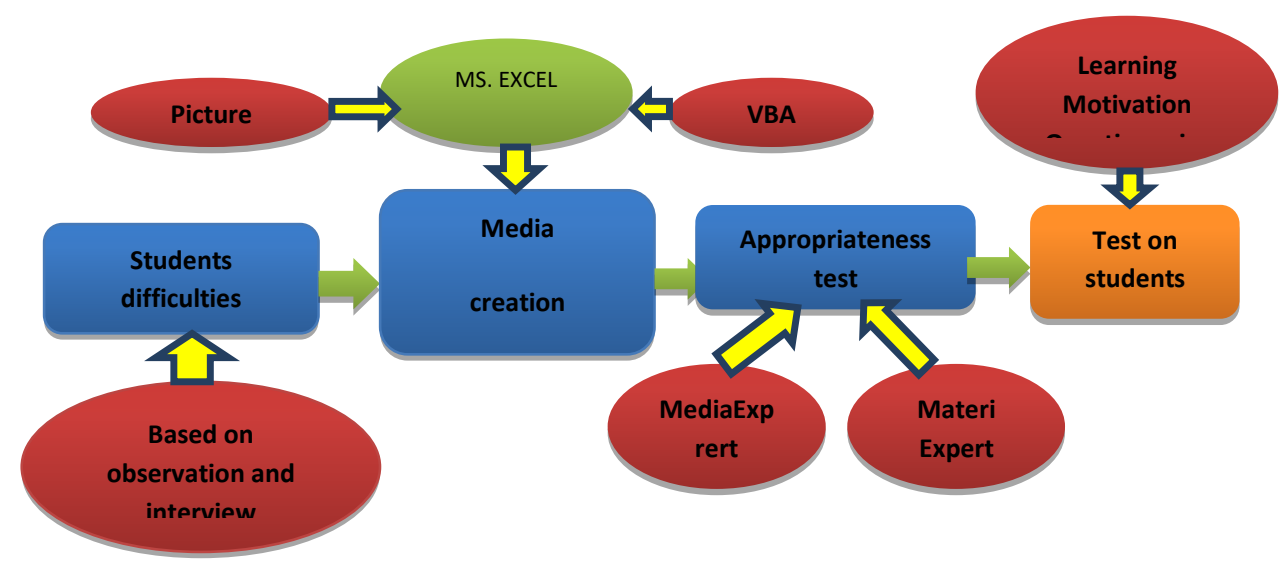

Figure 1. Media Making Design Plan

Figure 1 explained a maths learning media about substraction and addition operation based on the difficulties, arranged from the meaning of integer up to how to operate positive and negative inregers using VBA for Excel. Before testing it to the students, the media was tested for its appropriateness by asking for comments from media expert and materials experts as an evaluation to develop the media.

Table 4. Comments from Media Expert and Material Experts

\begin{tabular}{|c|l|c|}
\hline \multicolumn{2}{|c|}{ Media Expert } \\
\hline No. & \multicolumn{1}{|c|}{ Media Scores } & \multicolumn{1}{c|}{ Comments as Evaluation } \\
\hline 1 & The picture was very attractive & $\begin{array}{c}\text { A note of right or wrong could be added } \\
\text { to the students results by using pictures } \\
\text { or a change of colors }\end{array}$ \\
\hline 2 & $\begin{array}{l}\text { The instruction and order keys were } \\
\text { interactive and attractive enough, } \\
\text { substraction operation between 2 integers. }\end{array}$ & \\
\hline 3 & $\begin{array}{l}\text { The language program VBA for Excel was } \\
\text { quite simple and effective }\end{array}$ & \multicolumn{1}{|c|}{ Material Experts } \\
\hline \multicolumn{1}{|c|}{ Material Scores } & Comments as Evaluation \\
\hline No. & \multicolumn{1}{|c|}{$\begin{array}{l}\text { The need to develop media by students' } \\
\text { basic knowledge up to concept }\end{array}$} \\
\hline 1 & $\begin{array}{l}\text { The steps rules by pictures were quite } \\
\text { attractive }\end{array}$
\end{tabular}




\begin{tabular}{|c|l|l|}
\hline & & understanding. \\
\hline 2 & $\begin{array}{l}\text { Creativitiy in making media in introducing } \\
\text { the process to use VBA for Excel }\end{array}$ & \\
\hline 3 & $\begin{array}{l}\text { Excellent in giving understanding to } \\
\text { primary school students }\end{array}$ & \\
\hline
\end{tabular}

Based on the comments in table 4, the media was designed again to make it better by adding attractive shapes or pictures so the students would be attracted to learn the number line. The media would then be divided into 4 steps that are a) the first meeting, explanation of positive integer, negative integer and zero; $b$ ) second meeting introducing the integer position using animated pictures using VBA for Excel; c) Third meeting, relating the maths symbols using shapes picture using VBA for Excel, d) Fourth meeting: students try and explain using media.

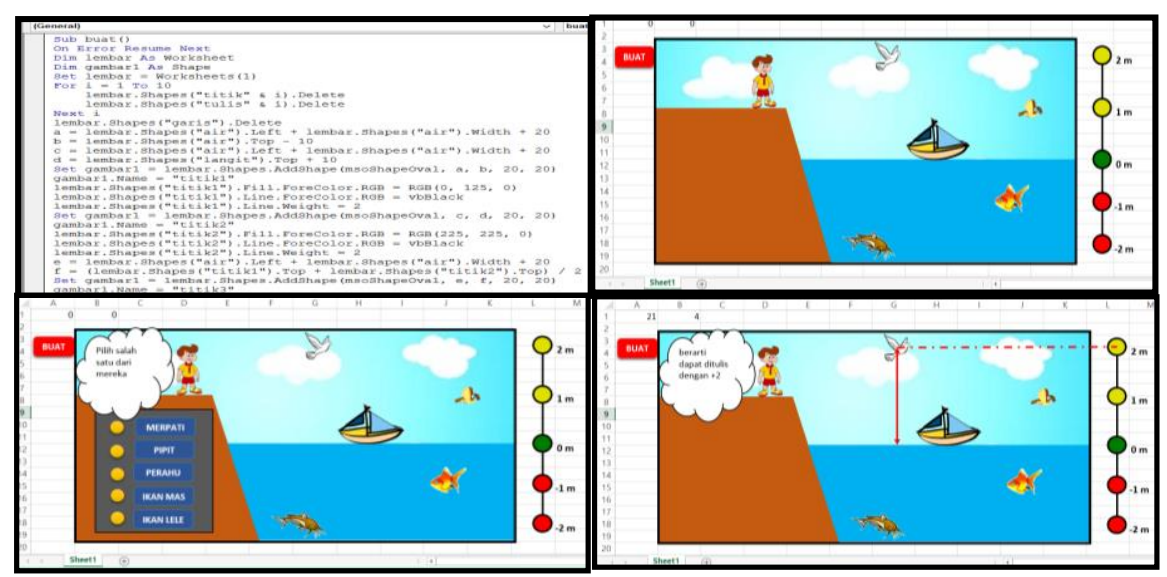

Figure 2. Developing VBA for Excel Media for second meeting

Picture 2 explained the story based on animated media about understanding of a student as an observer and 5 other observed objects based on the height of each objects from the pool surface, aiming at the understanding of students in positive integers, zero, and negative integer to encourage students to give reasons in his or her own language.
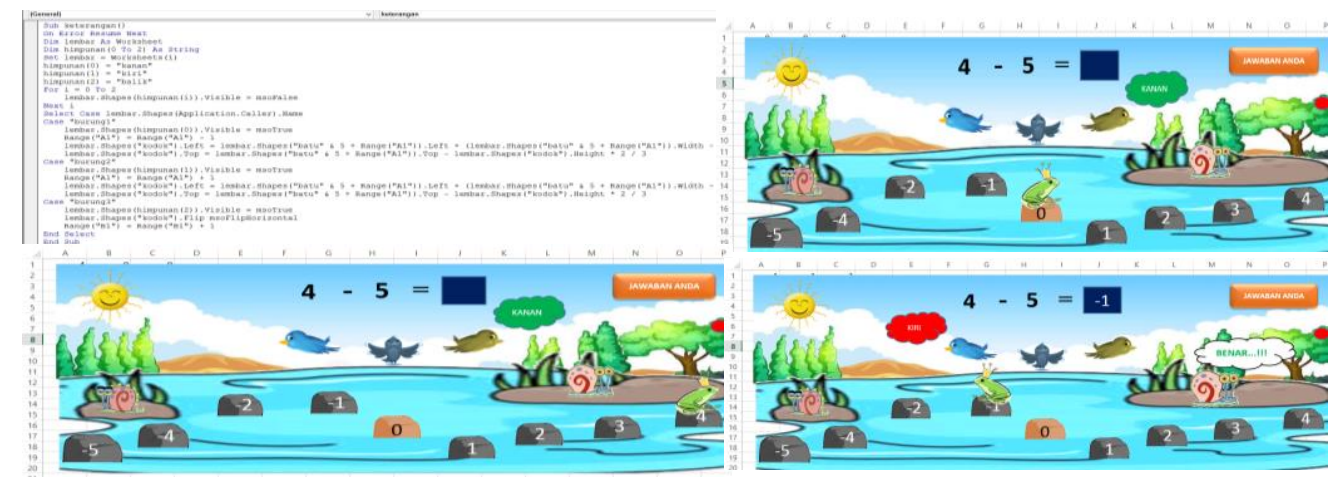

Figure 3. Developing the VBA for Excel game media for the 3rd meeting

Figure 3 described the result of the VBA for Excel media in games of integers in substraction and addition operations, which aims at 1) simplify the students to give the result in terms of solution 
for integers rules and maths operations; 2) Increasing students' attraction in solving problems; 3) Creating students' activity in playing a role in giving critical and creative statement through a new idea which comes up during doing questions.
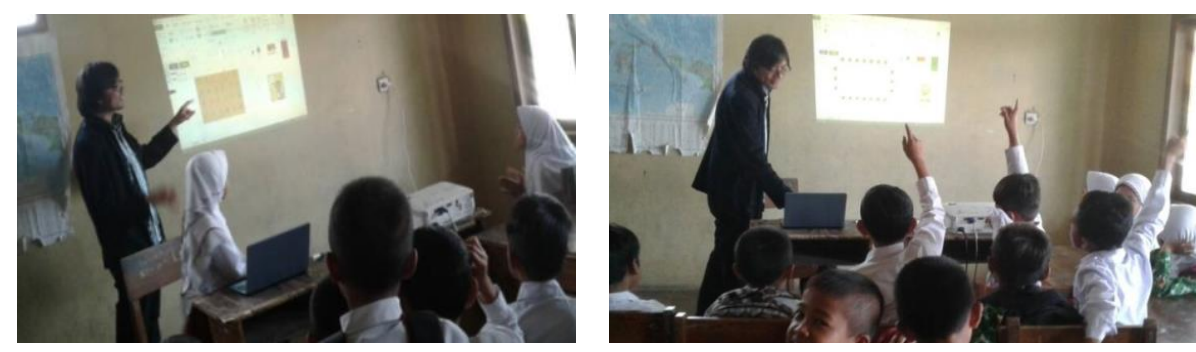

Figure 4. Implementing Excel Media to the students at the fourth meeting

Picture 4 described the students activity in class in solving problems by practising the media and giving explanations from the result based on the challenge questions given to the students, which was based on the observation in the field as explained in Table 5 about students' motivation based on learning using VBA for Excel, and motivation which can be seen according to the 6 indicators (Hendriana, Rohaeti, \& Sumarmo, 2017).

Table 5. Students' Motivation based on VBA for Excel Learning

\begin{tabular}{|c|c|c|}
\hline No. & Indicator & Students' Activity in Class \\
\hline 1 & $\begin{array}{l}\text { Desire and willingness to } \\
\text { succeed }\end{array}$ & $\begin{array}{l}\text { - Students try to solve problems explaining the reason } \\
\text { personally by using media. } \\
\text { - Students try to fix their mistakes when presenting it in } \\
\text { front of the class. }\end{array}$ \\
\hline 2 & $\begin{array}{l}\text { Encouragement and need in } \\
\text { learning }\end{array}$ & $\begin{array}{l}\text { - Students pay attention in the steps of the meaning of } \\
\text { integers and operation of integers through VBA for Excel } \\
\text { media. } \\
\text { - There is students' motivation to play a role actively in } \\
\text { solving problems. }\end{array}$ \\
\hline 3 & $\begin{array}{l}\text { Dreams and hopes in the } \\
\text { future }\end{array}$ & $\begin{array}{l}\text { Students' desire to develop maths questions by maths story } \\
\text { questions }\end{array}$ \\
\hline 4 & Compliments in Learning & $\begin{array}{l}\text { Students are happy and get some help in solving problems } \\
\text { using media. }\end{array}$ \\
\hline 5 & Attractive activity in learning & $\begin{array}{l}\text { Students are attracted in and would like to try seeing their } \\
\text { friends could explain the result form VBA for Excel media. }\end{array}$ \\
\hline 6 & $\begin{array}{l}\text { A condusive learning } \\
\text { enviroment }\end{array}$ & $\begin{array}{l}\text { There was a discussion between students and their friends } \\
\text { when a task was given and they were active in doing } \\
\text { questions. }\end{array}$ \\
\hline
\end{tabular}

Based on the observation in Table 5, there was an increase in students' understanding about integers and integer operation after an increment in students' motivation through VBA for Excel media as explained in Table 6. 
Table 6. Observation Result based on Students' Ability After Using Media

\begin{tabular}{|c|l|c|c|c|c|}
\hline No & \multicolumn{1}{|c|}{ Statement of Students' Ability } & Able & Percentage & Unable & Percentage \\
\hline 1 & $\begin{array}{l}\text { To know the meaning of positive } \\
\text { integer, zero and negative integer }\end{array}$ & 20 & $80 \%$ & 5 & $20 \%$ \\
\hline 2 & $\begin{array}{l}\text { Understanding, and solving the } \\
\text { operation of addition and } \\
\text { substraction between 2 integer }\end{array}$ & 22 & $88 \%$ & 3 & $12 \%$ \\
\hline 3 & Able to give final conclusion & 19 & $76 \%$ & 6 & $24 \%$ \\
\hline
\end{tabular}

Table 6 explained the result of the observation after learning using media VBA for Excel, there was an increase in students' ability from 3 indicators but there was $20 \%$ of the students who didn't understand the concept of positive integers, zero and negative integers, $12 \%$ of the students haven't understood the operation of addition and subtraction of integers, and $24 \%$ of the students haven't been able to give a conclusion to the final result. Several factorsin students' difficulties are: 1) It's easier to understand a real picture related to the integers rather than the illustration of a moving object; 2) Doubt in answering causing the student not brave enough to give the correct reason; 3) Limited opportunity of students to actively involved due to time limitation, all these 3 problems are considered to be evaluation materials in developing VBA for Excel media.

\section{CONCLUSION}

Based on the presented result and discussion, it can be concluded that from the average of overall score from all indicators, the students can be categorised into excellent, as there was $88.21 \%$ increment in students ability after using learning media based on VBA for Excel but there are several things needs to be improved that are 1) the need of picture concept to explain integers; 2) making steps that can guide student in order to understand maths more so there will be no doubt in giving reasons; and 3) Regulating the perfect time to give students the opportunity to solve the problems using media for excel.

\section{REFERENCES}

Arikunto, S. (2008). Prosedur Penelitian: Suatu Pendekatan Praktek. Jakarta: PT.Rineka Cipta.

Akbar, P., Hamid, A., Bernard, M., \& Sugandi, A. I. (2018). Analisis kemampuan pemecahan masalah dan disposisi matematik siswa kelas xi sma putra juang dalam materi peluang. Jurnal Cendekia: Jurnal Pendidikan Matematika, 2(1), 144-153.

Bernard, M., Novtiar, C., \& Rohaeti, E. E. (2020). Penerapan Permainan Operasi Bilangan Bulat Menggunakan VBA pada Guru Kecamatan Pangalengan. ETHOS: Jurnal Penelitian dan Pengabdian kepada Masyarakat, 8(1), 49-58.

Bernard, M., \& Sunaryo, A. (2020). Analisis Motivasi Belajar Siswa MTs dalam Pembelajaran Matematika Materi Segitiga dengan Berbantuan Media Javascript Geogebra. Jurnal Cendekia: Jurnal Pendidikan Matematika, 4(1), 134-143.

Bernard, M., Akbar, P., Ansori, A., \& Filiestianto, G. (2019). Improve the ability of understanding 
mathematics and confidence of elementary school students with a contextual approach using VBA learning media for Microsoft Excel. In In Journal of Physics: Conference Series (Vol. 1318, No. 1, p. 012035). IOP Publishing.

Bernard, M., Minarti, E. D., \& Hutajulu, M. (2018). Constructing Student 's Mathematical Understanding Skills and Self Confidence: Math Game with Visual Basic Application for Microsoft Excel in Learning Phytagoras at Junior High School. International Journal of Engineering \& Technology, 7(3.2), 732-736.

Bernard, M., \& Senjayawati, E. (2019). Developing the Students' Ability in Understanding Mathematics and Self-confidence with VBA for Excel. JRAMathEdu (Journal of Research and Advances in Mathematics Education), 1(1), 45-56.

Bernard, M., Sunaryo, A., Tusdia, H., Hendriani, E., Suhayi, A., Parida, M., ..., \&\& Rolina, R. (2019). Enhance Learning Independence and Self Ability of Exceptional Children Through Developing Learning Media VBA for Excel Games. In In Journal of Physics: Conference Series (Vol. 1315, No. 1, p. 012037). IOP Publishing.

Hendriana, H., Rohaeti, E. E., \& Sumarmo, U. (2017). Hard Skills \& Soft Skills Matematik Siswa. Cimahi: Refika Aditama.

Mahmud. (2015). Identifikasi Faktor-Faktor Yang Mempengaruhi Motivasi Belajar Mahasiswa Pada Mata Kuliah Stenografi di Program Studi Pendidikan Ekonomi Perkantoran Fakultas Ekonomi dan Bisnis Universitas Negeri Gorontalo. Aksara Jurnal Ilmu Pendidikan Nonformal, 1(4), 407-418.

Nugraha, N., Kadarisma, G., \& Setiawan, W. (2018). Analisis Kesulitan Belajar Matematika Materi Bentuk Aljabar Pada Siswa SMP Kelas VII. Journal on Education, 01(02), 323-334.

Pebriana. (2017). Peningkatan hasil Belajar Matematika dengan Menerapkan Pendekatan Pendidikan Matematika Realistik Indonesia (PMRI) pada siswa kelas V SDN 003 Bangkinang. Jurnal Cendikia: Jurnal Pendidikan Matematika, 1(1), 68-79.

Rizki, \& Widaniati. (2015). Efektifitas Bahan Ajar dan Media Berbasis ICT Pada Materi Persamaan dan Fungsi Kuadrat. AKSIOMA: Jurnal Progran Studi Pendidikan Matematika, 4(2).

Sunaryo, A. (2019). Penggunaan Media Pembelajaran Geogebra Terhadap Hasil Belajar Siswa Tentang Materi Program Linier Kelas X. Journal on Education, 2(1), 96-103.

Wiliawanto, W., Bernard, M., Akbar, P., \& Sugandi, A. I. (2019). Penerapan Strategi Pembelajaran Aktif Question Student Have Untuk Meningkatkan Kemampuan Berpikir Kritis Matematik Siswa SMK. Jurnal Cendekia: Jurnal Pendidikan Matematika, 3(1), 139-148. 